\title{
Hispanismes
}

Revue de la Société des Hispanistes Français

\section{A potência do pequeno}

\section{Notas sobre "A menor mulher do mundo" de Clarice Lispector}

La puissance des petits. Notes sur «A menor mulher do mundo » de Clarice

Lispector

La potencia de los pequeños. Notas sobre «A menor mulher do mundo» de Clarice Lispector

The power of the small. Notes on "The Smallest Woman in the World" by Clarice Lispector

\section{Eliane Robert Moraes}

\section{(2) OpenEdition}

\section{Journals}

\section{Edição electrónica}

URL: https://journals.openedition.org/hispanismes/580

DOI: 10.4000/hispanismes.580

ISSN: 2270-0765

\section{Editora}

Société des Hispanistes Français

\section{Refêrencia eletrónica}

Eliane Robert Moraes, «A potência do pequeno », HispanismeS [En ligne], 15 | 2020, mis en ligne le 01 juin 2020, consulté le 31 juillet 2021. URL : http://journals.openedition.org/hispanismes/580 ; DOI : https://doi.org/10.4000/hispanismes.580

Este documento foi criado de forma automática no dia 31 julho 2021.

Les contenus de cette revue sont mis à disposition selon les termes de la Licence Creative Commons Attribution - Pas d'Utilisation Commerciale - Pas de Modification 4.0 International. 


\title{
A potência do pequeno
}

\author{
Notas sobre "A menor mulher do mundo" de Clarice Lispector
}

La puissance des petits. Notes sur «A menor mulher do mundo » de Clarice

\section{Lispector}

La potencia de los pequeños. Notas sobre «A menor mulher do mundo» de Clarice Lispector

The power of the small. Notes on "The Smallest Woman in the World" by Clarice Lispector

\section{Eliane Robert Moraes}

... ela pertencia a uma resistente raça anã teimosa que um dia vai talvez reivindicar o direito ao

grito.

Clarice Lispector, A hora da estrela

\section{"Sentir viagem"}

1 Em dezembro de 1943, Clarice Lispector publica seu primeiro livro, intitulado Perto do Coração Selvagem. Meio ano depois, ela atravessa o Atlântico numa sinuosa viagem rumo à Europa, vindo a desembarcar no oeste africano em 31 de julho de 1944, para uma escala que se estende por dois dias. Suas notas sobre essa brevíssima temporada na África poderiam muito bem partilhar o título do romance de estreia, na medida em que registram a primeira aproximação da então jovem escritora ao coração selvagem desse continente que ela qualifica de "indomável" e, mais tarde, reconhece como "o nascedouro do mundo"1.

2 A maior parte dessas anotações foi escrita no calor da hora, em uma caderneta pessoal, por ocasião da sua chegada à base aérea dos Estados Unidos em Fisherman's Lake, na Libéria, onde Clarice dormiu uma noite. Nelas, misturam-se impressões de viagem com registros de sensações físicas, desejos e expectativas de futuro, além de descrições e comentários diversos sobre o que acontecia fora - e também o que se passava dentro dela. Lidos em conjunto, esses apontamentos parecem se oferecer como a primeira 
palpitação do conto "A menor mulher do mundo", que seria publicado originalmente em 1959, na revista Senhor e, no ano seguinte, na coletânea Laços de família. Por tal razão, vale a pena reproduzi-las, senão na íntegra, ao menos em suas passagens mais expressivas, notadamente aquelas que podem esclarecer a relação acima, como as que se seguem, datadas de 31 de julho de 1944, dia da chegada:

As negras de busto nu nas vilas onde os missionários não chegaram. [...] Um negro, a quem eu dei adeus e sorri mais demoradamente, de propósito, ficou encantado e pôs a mão no [rasurado]. As negras jovens pintam o rosto com traços de cor creme e o lábio inferior com uma tinta da cor de azinhavre. Uma delas pediu-me meus sapatos. Outra, a quem agradei o filhinho, disse: Baby nice, baby cry money. Um dos rapazes deu-lhe um níquel, ela disse: baby cry big money. Uma falou alguma coisa longa e complicada. Vi que era a meu respeito e ela ria. (eles riem com grande facilidade, mas alguns são tristes e mesmo o riso deles é de humildade e fascinação.) Pergunto a um deles, que sabia inglês, o que ela dissera: ele tentou resumir, disse afinal: that you are fine, she likes you. Perguntaram sobre o meu lenço de cabeça. Eu tirei para ensinar a botar e quando eles viram meus cabelos ficaram sérios e atentos.

Entramos numa loja pobre, quase sem nada. O homem ria, ria de alegria da gente ter entrado lá. Aquele tambor também para chamar todos. [...]

Ah, o corpo, o corpo. Como é difícil arranjar uma posição confortável para ele! [...]

Como é limpo o tempo que não é dividido em tarefas. [...]

O incompreensível está salvo dos indiscretos.

Fisherman's Lake não é ilha. Libéria é uma república independente, de negros. [...] Perto não há nenhuma cidade. Vi alguns negros. Bonitos, limpos (por que estou falando deles como de animais? No entanto, gosto mais deles, de certo modo, do que dos portugueses com os quais viajo). [...] Parece-me que tanto faz estar na Libéria como no Brasil. Não sinto mudança de natureza, não sinto "viagem”! Pois agora uma mania de procurar poesia nas coisas, de se enternecer. É horrível isto e, no entanto, fácil e atraente. Não existirá um modo mais, digamos, austero e fino de ver as coisas? E no momento em que esse modo austero e fino for um abismo onde se cai com prazer, procurar um novo modo. Para não ofender as coisas. Ser leal com elas. Não enganálas. Não ver no mar imediatamente o verde, o brilho, as ondas, o poder, a calma. Se não puder ver mais nada, o silêncio será mais simples e mais puro como atitude. Mesmo as melhores pessoas caem no veio de sentir.

Ontem no avião experimentei de tal forma o desejo de ter um filho que me senti nova, forte, criada. [...]

Amanhã, às oito horas (parece), tomaremos o avião; depois de três horas e pouco de voo, chegaremos a Bolama, possessão portuguesa, onde almoçaremos ${ }^{2}$.

3 Não é difícil, ao leitor familiarizado com o conto, perceber as possíveis repercussões dessas notas no texto que será escrito por volta de dez anos mais tarde. Do busto nu das mulheres, que por certo desafiava a severa moralidade dos missionários, ao riso fácil dos nativos que devia confundir os viajantes por expressar sentimentos paradoxais como alegria, tristeza, encantamento, humildade ou fascinação; do intento de encontrar uma posição confortável para o próprio corpo às estranhas reações precipitados pelo corpo do outro; do tempo que não se mede pela produtividade das tarefas até o tambor usado como legítimo meio de comunicação - tudo naquele lugar, que parecia distante de tudo, demandava uma compreensão mais profunda, que ultrapassasse as aparências. Até a visão imediata dos corpos - "bonitos, limpos" - era colocada em suspeita, por talvez encobrir o mais impiedoso dos preconceitos: ver os outros como se fossem animais.

4 Se mães e futuras mães se confraternizavam no círculo da espécie humana, dela eram excluídos aqueles africanos que colocavam a mão no lugar "errado", tal qual a protagonista do conto, flagrada no constrangedor ato de se coçar "onde uma pessoa não 


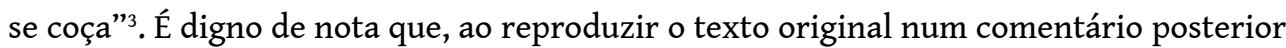
sobre a mesma viagem, Clarice tenha "corrigido" o episódio do moço que se encantou com ela "e pôs a mão no [...]", preenchendo a rasura com as seguintes palavras:

Sou extremamente examinada por um negro jovem e, sem saber o que fazer, termino por lhe dar adeus, já que eles gostam tanto de dar adeus. O rapaz fica encantado e, com aplicação, numa delicadeza de oferenda, ingênuo e puro, faz gestos obscenos ${ }^{4}$.

5 Nada mais distante da mentalidade dita civilizada do que uma obscenidade casta e pura. Nada mais difícil, convenhamos, de se compreender.

o que se impõe diante da escritora em sua escala na África é, definitivamente, o desconhecido, a demandar "um modo mais, digamos, austero e fino de ver as coisas". Era preciso procurar esse novo modo de ver "para não ofender as coisas", para "ser leal com elas", para "não enganá-las". Tratava-se, em suma, de "não ver no mar imediatamente o verde, o brilho, as ondas, o poder, a calma" - ou seja, de resistir à enganosa claridade do óbvio para poder reconhecer as opacidades que se escondem nas profundezas marinhas. Tratava-se, igualmente, de não reduzir os africanos às impressões imediatas, estas não raro acomodadas a estereótipos etnocêntricos, preconceituosos e ofensivos quase sempre disfarçados de "obviedades".

7 Nenhum apelo ao exotismo se faz notar nos apontamentos de Clarice. Muito pelo contrário. Em carta a Lucio Cardoso, datada de 30 de setembro de 1944 e escrita em Nápoles, a autora faz um breve comentário sobre sua passagem pelo território africano, para dizer, não sem certa ironia: "Viajei com muitos missionários e olhando para uma mulherzinha santa que dormia em frente a mim [...] disposta a convencer todos os negros da África que não há necessidade de nada, senão de civilização. Na manhã seguinte chegamos a Fisherman's Lake, na Libéria, onde passamos um dia e uma noite. Eu precisava me repetir: isso é África - para sentir alguma coisa. Nunca vi ninguém menos turista. ${ }^{5}$ De certa forma, reitera-se na carta a observação feita em seu diário já na manhã da chegada, quando Clarice escreve que "tanto fazia estar na Libéria como no Brasil. Não sinto mudança de natureza, não sinto 'viagem'!"

"Sentir viagem" - a expressão estranha parece dizer mais do que aparentemente diz. Primeiro, porque nela a viagem é tratada mais como sentimento do que como acontecimento, pouco ou nada tendo em comum com o turismo. Assim também, o deslocamento implicado na ideia de "mudança de natureza" sugere uma superação das evidências factuais e a passagem para um patamar de impressões sensíveis bem menos evidentes. O que predomina na concepção clariciana é, em suma, um modo de viajar análogo ao modo de ver reivindicado por ela nos mesmos apontamentos, a saber, aquele modo "mais austero e fino" no qual a transfiguração das coisas, possibilitada pela atividade criadora, pudesse constituir - e reconstituir - a paisagem. Tudo leva a crer que, para a autora, esse modo será dado pela escrita.

9 É o que se conclui do último texto de Clarice sobre aquela experiência de viagem, este já devidamente aquilatado pelo trabalho da memória, uma vez que se apresenta francamente como lembrança do passado, talvez registrada um quarto de século depois do episódio africano. Publicado no Jornal do Brasil em 1971, numa sequência de crônicas sobre viagens, o caráter de rememoração se reforça desde o título, "Estive em Bolama, África", ao qual se seguem as considerações abaixo:

Também por desvio de rota, eis-me na possessão portuguesa africana, Bolama. Lá tomei breakfast e vi os africanos. Os portugueses, pelo menos aqueles que eu vi, tratavam os negros a chicote. Falam os negros um português de Portugal 
engraçadíssimo. Perguntei a um menino de seus oito anos que idade tinha. Respondeu: 53 anos de idade. Caí para trás. Perguntei ao português que me acompanhava no breakfast: como é que se explica isso? Ele respondeu: não sabem a idade, a senhora podia perguntar àquele velho a sua idade e ele poderia the responder dois anos. Perguntei: mas é necessário tratá-los como se não fossem seres humanos? Respondeu-me: de outro modo eles não trabalham. Fiquei meditativa. A África misteriosa. Neste mesmo momento em que alguém me lê, lá está a África indomável vivendo. Lamento a África. Gostaria de poder fazer um mínimo que fosse por ela. Mas não tenho nenhum poder. Só o da palavra, às vezes. Só às vezes ${ }^{6}$.

Muita coisa muda aqui, se comparado com as notas de 1944. Aliás, para empregar o termo cunhado pela autora, essas lembranças representam igualmente um "desvio de rota", inclusive por não oferecerem um quadro imediato e organizado. 0 texto, feito de associações abruptas que desnorteiam o leitor, não faz qualquer menção a datas. Além disso, a notação geográfica sobre a antiga capital da Guiné só ganha importância por ser o pano de fundo do espetáculo atroz de crueldade que a escritora ali testemunha. Cena que lhe faz repensar a questão dos excluídos da espécie humana em chave histórica e, talvez, já associada ao Brasil, por se tratar de uma "possessão portuguesa". Mas a passagem para o âmbito público não apaga a responsabilidade pessoal que a escritora assumira antes: se, nas anotações originais da viagem, Clarice atribui a si mesma o preconceito ("por que estou falando deles como animais?"), ao ampliar seu alcance, ela não deixa de se incluir entre aqueles a quem acusa. Sem se render a fórmulas fáceis, e pronta a acolher as contradições, a narradora do fragmento de 1971 que denuncia a violência colonial também desfruta, colonialmente, de seu breakfast europeu que exclui os africanos. A cada linha, o relato ganha em complexidade e o incógnito se mostra mais e mais eloquente, atestando a dificuldade, senão a impossibilidade, de se conhecer uma África tão dominada quanto indomável, tão explorada quanto misteriosa. Recordese que, segundo ela, o mais simples dos entendimentos da vida civilizada, o da notação numérica para a passagem do tempo, não é partilhado pelos habitantes de Bolama: para estes, as idades simplesmente inexistem, nem a história e, a bem da verdade, nem o tempo tal qual o concebemos.

11 Ora, esse lugar onde não existem datas e idades já é uma Bolama transfigurada pela memória e convertida em um mundo outro, com tempo e espaço próprios, a precipitar o sentimento de viagem. Ou seja: para ela, o deslocamento só se efetiva nas situações paradoxais em que a distância se torna condição de proximidade para permitir a ciência das coisas. O simples ato empírico de testemunhar os fatos de perto não garante acesso ao conhecimento. É o que sustenta Raúl Antelo ao propor uma fértil comparação entre o relato clariciano e um escrito de Henri Michaux que explora a mesma ordem de inquietações, partindo de uma pergunta que poderia perfeitamente ter sido assinada por Lispector: "Onde fica a viagem?". Observa o intérprete:

Quase no fim do percurso de Ecuador (1929), navegando o Amazonas como turista aprendiz, Henri Michaux pergunta-se "mais où est l'Amazone ?", o que o conduz a uma pergunta ontológica mais capital ainda, "Mais, où est-il ce Voyage?". Embora Michaux esteja no rio, navegue por ele, ele não vê o rio. Para vê-lo é preciso subir, vê-lo do alto, não basta a horizontalidade do deslocamento, mas exige-se, fundamentalmente, a verticalidade da abstração, uma cartografia, uma fiç̧ão. "Il faut l'avion", a técnica, os dispositivos da Europa, a linguagem, o poder. "Je n'ai donc pas vu l'Amazone". Em outras palavras, vivência não é experiência7.

12 Consciente de só ver o Amazonas através da escrita, Michaux antecipa a aventura de Michel Leiris em L'Afrique fantôme - extenso diário de campo de uma expedição realizada entre 1931 e 1933, que não cede à convenção etnográfica de descrever uma 
cultura distante. 0 próprio título do livro deixa claro que o autor não se propõe ali a realizar um balanço dos fatos testemunhados, o que confirma no fim do percurso, quando declara ter destruído 'o mito da viagem enquanto meio de evasão'. Ao comentar essa passagem, Fernanda Arêas Peixoto observa que a narrativa aponta "para a desmistificação da viagem, das realidades encontradas e do próprio trabalho etnográfico como possibilidade de acesso ao "outro"'s. Certo de não alimentar ilusões como essas, o que Leiris realmente faz, completa Antelo, é descrever "a si mesmo estudando essa cultura. Em uma palavra, vê-se vendo".

Como que pactuando a mesma disposição de seus pares franceses, Clarice conclui: "neste mesmo momento em que alguém me lê, lá está a África indomável vivendo". Escritora-viajante, ela relaciona duas experiências que se desenrolam paralela e simultaneamente - a do texto e a da vida - sabendo que nada, ou quase nada, garante a existência de um ponto de contato entre uma e outra. Nada, ou quase nada, é forçoso insistir, pois as entrelinhas deixam entrever uma tênue esperança de que a palavra possa ser compartilhada e, quiçá, valer-se de seu poder transformador: "Lamento a África. Gostaria de poder fazer um mínimo que fosse por ela. Mas não tenho nenhum poder. Só o da palavra, às vezes. Só às vezes".

\section{"Reduzida à profundeza"}

É no coração selvagem da misteriosa África de Clarice que o leitor surpreende os singulares protagonistas de "A menor mulher do mundo". Lê-se nos parágrafos iniciais do conto:

Nas profundezas da África Equatorial o explorador francês Marcel Pretre, caçador e homem do mundo, topou com uma tribo de pigmeus de uma pequenez surpreendente. Mais surpreso, pois, ficou ao ser informado de que menor povo ainda existia além de florestas e distâncias. Então mais fundo ele foi.

No Congo Central descobriu realmente os menores pigmeus do mundo. $\mathrm{E}$ - como uma caixa dentro de uma caixa, dentro de uma caixa - entre os menores pigmeus do mundo estava o menor dos menores pigmeus do mundo, obedecendo talvez à necessidade que às vezes a Natureza tem de exceder a si própria.

Entre mosquitos e árvores mornas de umidade, entre as folhas ricas do verde mais preguiçoso, Marcel Pretre defrontou-se com uma mulher de quarenta e cinco centímetros, madura, negra, calada. "Escura como um macaco", informaria ele à imprensa, e que vivia no topo de uma árvore com seu pequeno concubino. Nos tépidos humores silvestres, que arredondam cedo as frutas e lhes dão uma quase intolerável doçura ao paladar, ela estava grávida.

Ali em pé estava, portanto, a menor mulher do mundo. Por um instante, no zumbido do calor, foi como se o francês tivesse inesperadamente chegado à conclusão última. Na certa, apenas por não ser louco, é que sua alma não desvairou nem perdeu os limites. Sentindo necessidade imediata de ordem, e de dar nome ao que existe, apelidou-a de Pequena Flor. E, para conseguir classificá-la entre as realidades reconhecíveis, logo passou a colher dados a seu respeito (p. 77).

A abertura do conto adota um tom francamente jornalístico e pouco se identifica nela da voz literária de Clarice, em geral mais sinuosa e elusiva, além de nada afeita ao didatismo referencial que marca tais parágrafos. Reconhece-se aí uma fala padrão que talvez não seja muito diferente da que se ouvia nos telejornais da década de 1950, quando se implantou a televisão no país, exibidos diariamente em horário nobre com o intuito de formar e informar a família brasileira. Note-se que, nessas passagens, o narrador se vale de uma série de comparações simples, não raro buscando efeitos 
épicos ou poéticos supostamente ao gosto do "grande público", sem falar na preferência pelo recurso estilístico das repetições, cuja inflexão professoral será ainda mais marcante na sequência do texto.

De fato, o trecho que se segue, mantendo o padrão da linguagem formal e objetiva, desliza da informação jornalística para a explicação científica, na tentativa de mimetizar o tom dos estudos etnográficos, notadamente aqueles de viés positivista. Os likoualas - "raça de gente" a que pertence a pigmeia então batizada de Pequena Flor -, são descritos em seus principais atributos, a começar pelo fato de serem um grupo em extinção. Susceptíveis a toda sorte de precariedades sanitárias e alimentares, também são presas frequentes das "feras rondantes" e sobretudo dos "selvagens bantos" que "os caçam em redes, como fazem com os macacos. E os comem. Assim: caçam-nos em redes e os comem" (p. 78). Determinado a deixar tudo absolutamente às claras, o narrador detalha os acanhados hábitos cotidianos da "racinha de gente", cuja linguagem breve e simples se limita a poucos nomes, gestos e sons animais. Destaque é dado ao tambor, um "avanço espiritual" que lhes serve de utensílio quando dançam sob a proteção de um pequeno machado.

17 Ora, para colher todos esses dados a respeito da Pequena Flor, o explorador francês ostenta uma disposição típica do universo investigativo das ciências naturais, marcada pelo distanciamento e pela formalidade, e introduzida em suas facetas mais caricaturais. A relação de Marcel Pretre com a pigmeia é quase sempre definida por meio de estereótipos, clichês e lugares-comuns, que se acumulam no decorrer da narrativa ora na voz do narrador, ora na do personagem, cujos discursos convergem até o ponto de se tornarem indistintos. Elemento de multiplicação, a paródia se constitui como um dos principais procedimentos estruturantes da narrativa, e vários intérpretes apontam diálogos com outros gêneros literários (do conto de fadas ao roman noir) e também cinematográficos (dos documentários científicos aos filmes de terror). Escusado dizer que, nas mãos da escritora, o expediente é levado a uma espécie de exaustão irônica de modo a terminar, quase sempre, por dizer o contrário daquilo que aparentemente afirma.

A justaposição de diálogos paródicos evidencia uma das principais operações simbólicas nas quais o conto investe intensa e vertiginosamente: a ampliação. Esta se faz presente também nas enumerações de que o texto se vale com frequência e na proliferação de enunciados hiperbólicos, cujo melhor exemplo talvez esteja na passagem em que Pretre se dá conta da magnitude de sua descoberta. Afirma o narrador: "Seu coração bateu porque esmeralda nenhuma é tão rara. Nem os ensinamentos dos sábios da Índia são tão raros. Nem o homem mais rico do mundo já pôs olhos sobre tanta estranha graça. Ali estava uma mulher que a gulodice do mais fino sonho jamais pudera imaginar" (p. 79).

19 A tendência a tudo ampliar, agigantando sentimentos, sensações e valores, chega a contemplar o próprio título do conto, instaurando um paradoxo. Afinal, o pressuposto de que existe $a$ menor mulher do mundo supõe a conquista do lugar mais alto de determinada escala, que faz dela não só a menor dentre eles mas ainda a maior de todos. Nesse sentido ela se assemelha ao personagem Micrômegas de Voltaire, que ostenta no nome semelhante paradoxo ${ }^{10}$. Atente-se ao fato de que o texto afirma repetidamente a pequenez da pigmeia e reitera, categoricamente, que "entre os menores pigmeus do mundo estava o menor dos menores pigmeus do mundo, obedecendo talvez à 
necessidade que às vezes a Natureza tem de exceder a si própria". O menor dos menores escapa ao paradigma.

o paradoxo do título se repõe quando nos damos conta de que a outra operação simbólica estruturante do conto implica justamente o contrário da ampliação, a saber, a redução. Convém lembrar todavia que, na qualidade de movimentos excessivos da Natureza, ampliar e reduzir configuram atos não só opostos, mas igualmente complementares. Por vezes torna-se até mesmo impossível discernir um do outro, em especial quando são lançados ao horizonte do insondável. Ou seja: ampliação e redução são excessos quando supõem deslocamentos em direção ao inconcebível, engendrando situações que "o mais fino sonho jamais pudera imaginar".

Escusado lembrar que figuras da diminuição, da subtração e do encolhimento são soberanas na narrativa. Se as mais evidentes se manifestam nos recorrentes diminutivos - da "racinha de gente" ao "retratinho dela, coitadinha!", da "barriguinha do menor ser humano maduro" à "mulherzinha de intolerável doçura" -, uma das mais complexas se esboça quando o narrador diz que "não tendo outros recursos, [Pequena Flor] estava reduzida à profundeza" (p. 84). Redução essa que, assim formulada, se furta por completo à claridade e impede qualquer identificação a olho nu. Aliás, a exemplo do que ocorre com o fundo do mar, essa profundeza não se revela a quem divisa seus domínios, estes imersos na opacidade do desconhecido. É o que se confirma na leitura de outro texto de A descoberta do mundo que dialoga a fundo com "A menor mulher do mundo": "Mas ninguém encontraria nada se descesse às suas profundezas - senão a própria profundeza, como na escuridão se acha a escuridão." ${ }^{11}$

Estranha operação, que se torna mais enigmática quando manifesta uma das marcas claricianas por excelência, sintetizada por Yudith Rosenbaum como "o paradoxo da profundidade que se revela como superfície". Observa a intérprete, ao comentar a mesma passagem, que "o dentro e o fora se confundem e as fronteiras conhecidas perdem seus contornos. Já não há um externo ao qual se opõe um interno. Entre a casca e o interior pode haver pouca distância. Ou melhor, a casca pode ser o próprio interior. O que importa é a busca do que antecede a forma, seja ela qual for" ${ }^{\prime 2}$.

Para descrever tal busca, a autora de A maça no escuro se vale de uma imagem que concentra o sentido mais profundo do recurso da redução, seja nesse conto, seja em outras obras suas. Trata-se da "caixa dentro de uma caixa, dentro de uma caixa" que se impõe como emblema de uma procura infinita em cujo horizonte se revelaria a unidade infinitesimal da "matéria vivente"13. Ou, como propõe José Américo Motta Pessanha, aquilatando a urgência da redução para se chegar ao âmago de todo ser em que pulsa a vida:

[...] para chegar lá é preciso 'reduzir' ainda mais. é preciso ir ao ser humano, mas tão pouco, tão primitivamente humano, tão pequenamente humano, que se vai à 'Menor mulher do mundo'. E, como se não bastasse, à menor mulher do mundo que está grávida. Recuo antropológico e biológico: disfarce de redução fenomenológica. Busca da semente na semente - esta forma de já se estar buscando a essência. Como nesses artefatos da paciência chinesa que, dentro de pequeninas esferas de marfim, trabalha uma sucessão de esferas cada vez menores - num tender para zero que é a forma metafísica de se buscar a unidade mínima indispensável, esta essência ${ }^{14}$.

Por certo, o leitor familiarizado com a obra de Lispector logo reconhece as palavras acima em uma extensa série de figuras que compõem seu imaginário, todas elas aludindo de algum modo a tais formas mínimas de vida. Figuras sempre suscetíveis de desdobramentos uma vez que, para ela, "o que é vivo, por ser vivo, se contrai" ${ }^{15}$. Do ovo 
à água viva, da baba ao ectoplasma, da pulsação de uma tartaruga arfando à massa interior de uma barata moribunda, o obstinado desejo da autora no sentido de conhecer o mais ínfimo sopro de vida passa invariavelmente por uma vertiginosa interrogação do que é insuficiente, insignificante ou mesmo informe. Note-se que Pequena Flor, este raríssimo exemplar de uma racinha de gente condenada à extinção, ganha uma qualificação muito particular: "Foi, pois, assim que o explorador descobriu, toda em pé e a seus pés, a coisa humana menor que existe" (p. 79, grifos nossos).

De grande força expressiva, a associação desses dois termos pede esclarecimento. Afinal, o que seria a coisa humana?

Lê-se num verbete intitulado "Homem" que a revista Documents, dirigida por Georges Bataille, publica em 1929:

Homem. - Um eminente químico inglês, o Dr. Charles Henry Maye, empenhou-se em estabelecer de forma exata de que é feito o homem e qual é seu valor químico. Eis os resultados de suas sábias pesquisas. A gordura de um corpo humano de constituição normal seria suficiente para fabricar sete porções de sabonete. Encontram-se no seu organismo quantidades suficientes de ferro para fabricar um prego de espessura média e de açúcar para adoçar uma xícara de café. o fósforo daria para 2.200 palitos de fósforo. 0 magnésio forneceria matéria para se tirar uma fotografia. Ainda um pouco de potássio e de enxofre, mas em quantidade inutilizável. Essas diversas matérias primas, avaliadas na moeda corrente, representam uma soma em torno de 25 francos $^{16}$.

Essa imagem perturbadora, que decompõe o ser humano em porções para definir "de forma exata do que ele é feito", evoca com terrível poder de síntese a redução do corpo humano a um quase nada. $O$ verbete - atribuído a Bataille ou, pelo menos, produzido por ele a partir de eventuais registros das "sábias pesquisas" de algum positivista supõe um princípio radicalmente materialista: no fim das contas, já não há mais seres nem corpos, mas apenas frações de matéria que, devidamente separadas e medidas, poderiam servir como substância empregada na composição de certos produtos, independente de sua origem humana. De acordo com as quantidades de gordura, fósforo, ferro ou sangue, imagina-se o potencial correspondente de sabonetes, palitos ou pregos. No horizonte desses cálculos talvez resida o pesadelo de uma dissolução química dos corpos, a sugerir uma impiedosa antecipação da realidade: dez anos depois da publicação do artigo, esse pesadelo realmente se efetiva nos processos de "liquidação industrial" levados a termo pelo nazismo.

De fato, as formas "científicas" de decomposição reproduzidas na Documents remetem inexoravelmente à degradação dos corpos: nessas imagens o ser humano é confrontado com a sua condição de matéria, perecível e reciclável, cuja evidência mais dramática se manifesta no aspecto definitivo do cadáver. Por coincidência, em que pesem os distintos contextos dos escritos de Bataille e de Lispector, semelhante redução ao cadáver será evocada de maneira eloquente numa das páginas mais impactantes de "A menor mulher do mundo".

Trata-se da passagem em que o narrador invade a intimidade dos leitores de um jornal de domingo que publica a foto da diminuta criatura em tamanho natural. Como quem abre uma nova caixa na narrativa, ele segue de apartamento em apartamento para colher novos dados: num salto abrupto do coração da selva africana para o cenário urbano contemporâneo, ele investiga o impacto da imagem da pigmeia nas famílias de classe média brasileira que folheiam o suplemento dominical. De todas as cenas 
descritas, ganha relevo aquela em que a mãe de um menino devaneia diante de um espelho, recordando o que lhe contara uma cozinheira sobre sua infância num orfanato:

Não tendo boneca com que brincar, a maternidade já pulsando terrível no coração das órfãs, as meninas sabidas haviam escondido da freira a morte de uma das garotas. Guardaram o cadáver num armário até a freira sair, e brincaram com a menina morta, deram-lhe banhos e comidinhas, puseram-na de castigo somente para depois poder beijá-la, consolando-a. Disso a mãe se lembrou no banheiro, e abaixou mãos pensas, cheias de grampos. E considerou a cruel malignidade de nosso desejo de ser feliz. Considerou a ferocidade com que queremos brincar.E o número de vezes em que mataremos por amor. Então olhou para o filho esperto como se olhasse para um perigoso estranho. E teve horror da própria alma que, mais que seu corpo, havia engendrado aquele ser apto à vida e à felicidade. Considerou a malignidade de nosso desejo de ser feliz. Considerou a ferocidade com que queremos brincar. E o número de vezes em que mataremos por amor. Então olhou para o filho esperto como se olhasse para um perigoso estranho. E teve horror da própria alma que, mais que seu corpo, havia engendrado aquele ser apto à vida e à felicidade. Assim olhou ela, com muita atenção e um orgulho inconfortável, aquele menino que já estava sem os dois dentes da frente, a evolução, a evolução se fazendo, dente caindo para nascer o que melhor morde. 'Vou comprar um terno novo para ele', resolveu, olhando-o absorta. Obstinadamente enfeitava o filho desdentado com roupas finas, obstinadamente queria-o bem limpo, como se limpeza desse ênfase a uma superficialidade tranquilizadora, obstinadamente aperfeiçoando o lado cortês da beleza. Obstinadamente afastando-se, e afastando-o, de alguma coisa que devia ser 'escura como um macaco'. Então, olhando para o espelho do banheiro, a mãe sorriu e intencionalmente fina e polida, colocando, entre aquele seu rosto de linhas abstratas e a cara crua da Pequena Flor, a distância insuperável de milênios (p. 81-82).

$\mathrm{O}$ trecho concentra diversas sobreposições, evocando uma vez mais a imagem da caixa que se desdobra indefinidamente. Entre elas, Rosenbaum destaca a sobreposição de maternidades que passa pela mãe pigmeia, pelas meninas mães do orfanato e pela mãe do garoto: "Tantos jeitos de viver a mesma função biológica - desde aquela que está mais aderida à natureza, a mulher africana, até a carência perversa das órfãs, passando pela perplexidade com a própria cria da mãe ao espelho". Perplexidade que, segundo a crítica, se impõe quando enfim a mãe sorri e coloca "entre seu rosto de linhas abstratas e a cara crua da Pequena Flor, a distância insuperável de milênios". A modernidade aparece aí como abstração de uma crueza condensada na pessoa da pigmeia: "é do abjeto enquanto magma primordial, morada informe de nossa ancestralidade, mundo pulsional de um fundo sem fundo, que o sujeito humano se distancia para se constituir, perdendo sua carnalidade, tornando-se abstrato, ou seja, genérico, alienado de sua singularidade" ${ }^{17}$.

31 Ora, assim interpretada, a passagem em questão abre um novo vislumbre sobre a figuração da coisa humana, que vem se acrescentar à ostensiva alusão ao cadáver. Esta, de apelo concreto, surge na imagem da menina morta escondida no armário do orfanato que, fazendo vezes de boneca, serve de objeto ao amor feroz das internas; a outra, de teor abstrato, se revela na condição do moderno sujeito civilizado que, reduzido aos ideais assépticos das sociedades industriais, fica privado da singularidade essencial que lhe confere o corpo. Faces distintas de uma mesma moeda, ambas as imagens são passíveis de paralelo com a terrível redução que Bataille reconhece no desencantado mundo moderno onde, alienados de sua força vital, os seres soçobram como restos materiais. Afinal, se a cena das órfãs expõe o horror do desamparo, o processo de reificação só faz reiterá-lo como ameaça contra o "ser apto à vida e à 
felicidade", criado para ser belo, polido, limpo e, sobretudo, distinto de "alguma coisa que devia ser "escura como um macaco"'. O horror trabalha em tempo integral, seja em laboratórios ou em câmaras de gás, seja nos porões dos orfanatos ou nos apartamentos citadinos.

Todavia, ainda que denuncie os signos da morte inscritos nesses impiedosos devires, a coisa humana de Lispector não se esgota no apelo ao inanimado, marcando distância do caráter finalista que dá o tom do verbete batalliano. No fundo sem fundo explorado pela escritora há sempre uma nova dimensão a ser descoberta, como atenta Berta Waldman ao analisar o texto: "ao mesmo tempo em que se desconstrói um modelo cristalizado de racionalidade, de cultura, de ciência, emerge o exame do informe, da matéria humana minúscula, quase reduzida a nada, e, no entanto, pulsante". Daí a conclusão de que "se, por um lado, o trabalho do explorador é o de tentar afastar a pigmeia da espécie humana, de outro, o movimento da pigmeia é o de impor sua humanidade despossuída de acréscimos civilizacionais, espécie de humanidade em estado puro." ${ }^{18}$

Forçoso lembrar que o significante coisa se reveste de significados plurais, ambivalentes e por vezes misteriosos nas mãos de Clarice, nem sempre conformado aos termos que tradicionalmente estão a ele associados como objeto, produto, utensílio ou qualquer outro aparato material sem vida. Para a autora de Legião estrangeira, coisa pode realmente ser muita coisa ou até mesmo qualquer coisa, por vezes esbarrando na ambiguidade expressa por termos vagos como os brasileiros troço, treco, negócio, joça, sem excluir os sentidos equívocos que a psicanálise empresta à expressão Das Ding ${ }^{19}$. Em meio a tal polifonia, ganha singular força a evocação da palavra numa contundente nota da escritora sobre a origem do conto, que lhe teria sido sugerido por um artigo de jornal norte-americano em torno de uma pigmeia. Já mãe, com filho no colo num dia de verão, a notícia lhe inspira reflexões candentes sobre a coisa vivente:

"A Menor Mulher do Mundo" me lembra domingo, primavera em Washington, criança adormecendo no colo no meio de um passeio, primeiros calores de maio enquanto a menor mulher do mundo (uma notícia lida no jornal) intensificava tudo isso num lugar que me parece o nascedouro do mundo: África. Creio que este conto vem de meu amor por bichos: parece-me que sinto os bichos como uma das coisas ainda muito próximas de Deus, material que não inventou a si mesmo, coisa ainda quente do próprio nascimento; e, no entanto, coisa já se pondo imediatamente de pé, e vivendo toda, e em cada minuto vivendo de uma vez, nunca aos poucos apenas, nunca se poupando, nunca se gastando ${ }^{20}$.

\section{"Grande escuridão"}

Búfalos, peixes, cachorros, baratas, macacos, baleias, cisnes, gatos, tartarugas, coelhos, corujas, cavalos, pintinhos, galinhas, galinhas e galinhas - a copiosa imaginação zoológica de Lispector caminha em paralelo a seu declarado e inesgotável amor pelos bichos. Daí que venha a ser tópica obrigatória para os exegetas de sua obra, sempre aberta à descoberta de novas potencialidades animais e não raro tangenciando o “incompreensível" que preside o apelo à coisa ${ }^{21}$. Aliás, é nessa aproximação que a autora parece apostar quando associa sua delicada protagonista aos bichos, por ser, como eles, "coisa já se pondo imediatamente de pé, e vivendo toda, e em cada minuto vivendo de uma vez". 

indivíduos minúsculos, que não excedem 13 centímetros de altura. A descrição desse país onde o herói passará longa temporada torna-se ocasião privilegiada para o autor criticar com humor, veemência e pessimismo as crenças e os valores de sua própria sociedade, revoltando-se contra o sistema de conquista colonial escravista então 
vigente em diversos pontos da Europa. Não surpreende que o personagem se mostre profundamente hostil à vida de seus compatriotas, o que o leva a rejeitar as tradições ditas "civilizadas" e, por consequência, a adotar hábitos e pontos de vista dos povos que visita.

Observa Kahn que, sendo irlandês, Swift ocupa "uma posição periférica dentro do próprio Imperio Britânico, posição essa que, sem dúvida, favorece o olhar crítico com relação ao imperialismo inglês". Da mesma forma, prossegue a comentadora, o conto da escritora brasileira enfoca "o confronto entre o colonizador e o colonizado emblemático para a relação entre os povos da era moderna ao colocar face a face o explorador francês e a africana Pequena Flor". À exemplo do autor de Gulliver, a criadora de Macabéa também fala de uma posição periférica, o que é determinante para a escolha da África como cenário do conto, pois, sendo associado aos atributos "escuro", primitivo e misterioso, "do ponto de vista brasileiro o continente se configura como lugar de barbárie" assim como "do ponto de vista europeu o Brasil faz parte do mundo bárbaro" 25 .

Jogos de espelhos que se impõem e se interpõem sobre as diferenças entre os exploradores de Swift e de Lispector, pois, "ao contrário de Gulliver, que se abre à experiência do outro, o cientista Marcel Pretre encarna o colonizador convencional, que se julga no direito de se apropriar da pequena selvagem" ${ }^{26}$. Igualmente distantes no tempo e no espaço, as obras se aproximam como discursos de alta voltagem crítica contra os abusos coloniais. Elemento essencial dessa crítica, cabe assinalar, é a disposição por parte dos dois escritores em deixar um espaço em branco - não preenchido e nem preenchível - que preserva a inviolabilidade das alteridades, em respeito ao que Kahn define como "natureza indecifrável do outro".

Prova disso é que Clarice insiste em manter Pequena flor na condição de "incompreensível", sem jamais explicar a escuridão de sua mudez, o abismo de seu sorriso ou sua capacidade de amar profundamente um anel ou uma bota. Recorde-se a passagem do conto que diz:

Há um velho equívoco sobre a palavra amor, e, se muitos filhos nascem desse equívoco, tantos outros perderam o único instante de nascer apenas por causa de uma susceptibilidade que exige que seja de mim, de mim!, que se goste e não de meu dinheiro. Mas na umidade da floresta não há desses refinamentos cruéis, e amor é não ser comido, amor é achar bonita uma bota, amor é gostar da cor rara de um homem que não é negro, amor é rir de amor a um anel que brilha. Pequena Flor piscava de amor, e riu quente, pequena, grávida, quente (p. 85 ${ }^{27}$.

Da mesma forma, Swift termina o romance lançando seu herói aos confins do inexplicável. É digno de nota que sua última aventura transcorra numa terra ignota onde vivem cavalos de extraordinária inteligência, os Houyhnhnms, que teriam domesticado os homens, ali chamados de yahous, transformando-os em bestas cruéis e sem linguagem. Gulliver admira essa civilização e se abandona voluntariamente ao aprendizado de seus hábitos e de sua língua. Muito tempo transcorre até que se vê obrigado a retornar à sua pátria, mas de tal forma a companhia dos compatriotas lhe é insuportável que, passados cinco anos, ele ainda se sente um completo estrangeiro ao lado deles. Homem culto e experiente, no seu estábulo vivem dois cavalos, com os quais ele conversa quatro horas por dia.

Se o desfecho das Viagens de Gulliver se reveste de inegável opacidade, aquele de "A menor mulher do mundo" não é menos enigmático. Vale evocar o fim do relato, quando, depois de ter se perturbado "como só homem de tamanho grande se perturba", 
o explorador "se chamou à ordem, recuperou com severidade a disciplina de trabalho, $\mathrm{e}$ recomeçou a anotar". Mesmo assim, diante das reações ininteligíveis da pigmeia, ele "pestanejou várias vezes". Completa o narrador, retornando ao prédio de apartamentos onde os moradores ainda contemplavam a foto no jornal:

Marcel Pretre teve vários momentos difíceis consigo mesmo. Mas pelo menos ocupou-se em tomar notas. Quem não tomou notas é que teve de se arranjar como pode:

- Pois olhe - declarou de repente uma velha fechando o jornal com decisão -, pois

olhe, eu só lhe digo uma coisa: Deus sabe o que faz (p. 85).

A passagem joga com ambiguidades que geram leituras e interpretações distintas. Para Daniela Kahn, a inesperada presença de uma idosa na lista dos inquiridos por Pretre supõe uma abertura no conto, "como a dizer que um ponto de vista não é algo imutável, mas passível de ser modificado e enriquecido pelo amadurecimento, pela experiência de vida e até mesmo pela crença numa ordem superior à humana" ${ }^{28}$. Já Yudith Rosenbaum vê aí mais uma tentativa de apaziguamento da angustia precipitada "pelo que não tem nome" e, comparando a reação imediata da velha com o iluminismo programático do explorador, observa que: "para os que carecem de um bloco de notas, por um lado, ou da literatura, por outro, sempre existe a solução ex-machina, capaz de proteger os aflitos: 'Deus sabe o que faz'." 29

ja como for, é de se perguntar o que faz no texto uma frase feita como essa. Lugar comum das ladainhas das beatas brasileiras e das tagarelices de quem busca a salvação em fórmulas instantâneas, responderia ela ao desejo da escritora de fechar o conto com um toque de ironia? Ou, ao contrário, seria acaso um expediente literário "para não ofender as coisas", para "ser leal com elas" e para "não enganá-las"? Impossível saber ao certo, sobretudo quando se tem em mente que a rara criatura de desmesurada pequenez concebida por Lispector estava incluída no rol das "coisas ainda muito próximas de Deus".

Seria fácil ver aí uma declaração de fé da escritora, que se renderia a uma explicação de fundo criacionista para dar conta da presença dos animais no mundo. Seria, porém, um equívoco: se as evocações da deidade na literatura clariciana sempre se inscrevem no domínio da penumbra, não seria desta vez que ela abdicaria de sua obstinada vocação à incerteza. Aliás, assim como acontece com a enigmática palavra coisa, as menções da autora à figura divina se recobrem de tal complexidade que realmente se torna impossível fixá-las num sentido único e inconteste. E não será por isso mesmo que a passagem acima associa os dois significantes, preferindo aludir às coisas e não às criaturas "próximas de Deus", como que professando um estranho materialismo místico? E não será ainda por isso que esse conto termina igualmente por dizer "com espanto o nome de Deus"?

A frase se reveste de uma obscuridade que demandaria mais espaço do que este ensaio pode lhe dedicar, embora se possa ainda abordá-la obliquamente para tentar entender a particularidade desse chamamento. Resta saber que lugar cabe à imponência celestial nos minúsculos universos habitados por gente como os likoualas e os liliputianos.

No mais das vezes, o que está em questão no confronto entre a grandeza divina e aquilo que é menor, mais baixo ou mesmo insignificante, é a própria condição humana, a testemunhar sua irremediável queda e consequente miséria. Embora tal perspectiva não escape aos textos de Lispector e de Swift, ela não deixa de ser subvertida quando eles atribuem um sentido positivo às figuras do pequeno, quase sempre em comparação 
com a ostensiva pequenez dos que se vangloriam de seu tamanho avantajado. Recordese que Gulliver reconhece a superioridade moral de seus miúdos anfitriões assim como o irônico narrador clariciano não deixa de denunciar os disparates dos "grandes" diante da singela pigmeia.

Porém, mais importante ainda que o elogio do diminuto é o fato de ambos os autores cultivarem um singular jogo de proporções que, oscilando entre o físico e o espiritual, vem perturbar as noções de medida humana estabelecidas na modernidade ocidental. Jogo ao qual não se tem dado atenção no caso do conto brasileiro, sendo pouco cogitado no caso do romance inglês, obscurecido pela notabilidade que a fábula das miniaturas ganhou na posteridade. Nunca é demais lembrar, pois, que Swift também narra em detalhe a passagem de Gulliver por Brobdingnag onde, capturado por gigantes, o personagem conhece aventuras ainda mais surpreendentes do que as vividas em Liliput. Por conta de seu tamanho então reduzido, ele quase se afoga numa tigela de leite ou é esmagado por uma maçã, passando igualmente maus bocados quando capturado por um macaco ou preso no focinho de um cachorro. Nesse mundo superlativo o herói vive sob o nome de Grildrig - significando "pequeno pedaço de homem" - até o dia em que sua "casa portátil" é carregada por uma águia e depois lançada ao mar, de onde ele será resgatado por um navio inglês.

Brobdingnag é o contraponto de Liliput: se o país de miniatura emula a "grandeza humana", o reino dos gigantes só faz realçar o destino tacanho da vida reservada a "insetos" como Gulliver. Colocado na situação inversa que caracterizava seu convívio com os liliputianos, o personagem é então reduzido à mais completa impotência, o que permite ao seu criador expor a fragilidade das bases sobre as quais se ergue a imagem do homem ocidental, deixando patente que o grande e o pequeno são valores relativos, que se implicam mutuamente. Talvez esteja justamente nesse particular, e não na ficção sobre os pequeninos, a afinidade maior entre as duas fabulações, a princípio tão distintas, permitindo a conclusão de que o tempo forte do romance e do conto reside numa interrogação de alto teor filosófico sobre a medida do humano.

Porém, longe de pretenderem dar uma resposta às questões que formulam, um e outro preferem manter viva a inesgotável pergunta que suas fábulas provocam, sem qualquer promessa de resolução no horizonte. Afinal, manter o estado de interrogação significa preservar o mistério, e é precisamente nesse ponto que a evocação de Deus ganha sentido em "A menor mulher do mundo", já que a simples menção ao nome divino é suficiente para que toda medida seja colocada à prova de sua insondável desmedida.

Entende-se por que Clarice potencializa, nesse conto, seu singular talento para transfigurar questões existenciais em problemas de composição, valendo-se à vontade dos expedientes literários da ampliação e da redução. Estes, não só se alternam mas também se embaralham até o ponto de perturbar por completo as proporções em jogo. É o que ocorre em mais uma passagem exemplar do texto, quando o explorador francês, sentindo um inesperado mal-estar, flagra a pigmeia rindo, quente e "gozando a vida" por ter "a inefável sensação de ainda não ter sido devorada":

E então ela estava rindo. Era um riso como somente quem não fala ri. Esse riso, o explorador constrangido não conseguiu classificar. E ela continuou fruindo o próprio riso macio, ela que não estava sendo devorada. Não ser devorado é o sentimento mais perfeito. Não ser devorado é o objetivo secreto de toda uma vida. Enquanto ela não estava sendo comida, seu riso bestial era tão delicado como é delicada a alegria (p. 84). 
55 uma existência, o bestial se reconcilia com o delicado e a morte é decididamente adiada. o menor e o maior se equivalem como potências do excesso, alheias a todas as classificações: reduzida à profundeza, Pequena Flor partilha da desmesura de Deus. Daí que, vedado a quem se expressa em linguagem articulada, o incompreensível venha precipitar uma estranha e exuberante fruição: "se a própria coisa rara estava rindo, era porque, dentro de sua pequenez, grande escuridão pusera-se em movimento" (p. 84).

O sopro da escuridão vibra em silêncio - e não conhece limites.

\section{BIBLIOGRAFIA}

Raúl ANTElo, “Mas onde fica a viagem?”, Confluenze - Rivista di Studi Iberi Americani, vol. 4, n¹ (2012). Bolonha, Dipartimento di Lingue e Letterature Straniere Moderne, Università di Bologna, p. 2.

Documents, $\mathrm{n}^{\circ}$ 4, Paris, Jean Michel Place, 1991, edição fac-simile.

Daniela Mercedes KAHN, “A menor mulher do mundo, de Clarice Lispector e a desmistificação do discurso da colonização”, Ângulo 111, Lorena, Unifatea, Out.-Dez, 2009.

Clarice LISPECTOR, A descoberta do mundo, Rio de Janeiro, Nova Fronteira, 1984.

Clarice LISPECTOR, Caderno de bordo, Rio de Janeiro, s/d, site do Instituto Moreira Salles, <URL : https://site.claricelispector.ims.com.br/acervo/caderno-de-bordo/>.

Clarice LISPECTOR, Laços de família, Rio de Janeiro, Rocco, 1983.

Clarice LISPECTOR, A legião estrangeira, Rio de Janeiro, Editora do autor, 1964.

Clarice LISPECTOR, Correspondências, Rio de Janeiro, Rocco, 2002, p. 54.

Alexandre NODARI e João Camillo PENNA (orgs.), “As mil coisas de Clarice”, Revista Letras, n 98 (Jul./ Dez. 2018), publicação semestral do Curso de Letras da UFPR, <URL : https://revistas.ufpr.br/ letras>.

Evandro NASCIMENTO, "Rastros do animal humano - a ficção de Clarice", Maria Esther MACIEL (org.), Pensar/Escrever o animal. Ensaios de zoopoética e biopolítica, Florianópolis, Editora UFSC, 2011, p. 117-149.

Wilton DE SOUZA ORMUNDO, Figurações do grotesco nas narrativas curtas de Clarice Lispector: o fenômeno como disparador do Unheimlich, das inversões e do (des)equilíbrio, Biblioteca Digital de Teses e Dissertações da USP, 2008, <URL : https://www.teses.usp.br/teses/disponiveis/8/8149/ tde-12082009-1 63845/pt-br.php>.

Fernanda ARÊAS PEIXOTO, “A viagem como vocação - Antropologia e literatura na obra de Michel Leiris", Michel LEIRIS, A África fantasma, trad. André Pinto Pacheco, São Paulo, CosacNaify, 2007, p. 19-33. 
Yudith ROSENBAUM, "Vozes estrangeiras em Clarice Lispector - Leitura de "Como uma corça”, Cleusa RIOS P. PASSOS e Yudith ROSENBAUM (orgs.), Interpretações. Crítica Literária e Psicanálise, Cotia, São Paulo, Ateliê Editorial, 2014.

José Américo MOTTA PESSANHA, “Clarice Lispector: O itinerário da paixão” In Clarice Lispector, A paixão segundo G.H., edição crítica coordenada por Benedito Nunes, Madri/Paris/México/Buenos Aires/São Paulo/Rio de Janeiro : ALLCA XX, Coleção “Archivos”, 1996.

Yudith RoSENBAUM, “Uma estranha descoberta. Leitura do conto 'A menor mulher do mundo', de Clarice Lispector”, Revista Literatura e Sociedade, vol. 20 (2015), São Paulo, FFLCH-USP, p. 148-156.

Carlos MENDES DE SOUZA, Clarice Lispector - Figuras da escrita, São Paulo, Instituto Moreira Salles, 2012.

Berta WALDMAN, "Duas mulherzinhas”, Entre passos e rastros. Presença judaica na literatura brasileira, São Paulo, Perspectiva, 2001.

\section{NOTAS}

1. Clarice LISPECTOR, “A explicação que não explica”, in Clarice LISPECTOR, A descoberta do mundo, Rio de Janeiro, Nova Fronteira, 1984, p. 365-366.

2. Clarice LISPECTOR, Caderno de bordo, site do Instituto Moreira Salles, Rio de Janeiro, s/d [disponível em 15/10/2020]<URL : https://site.claricelispector.ims.com.br/acervo/caderno-debordo > Os itálicos são todos nossos, e indicam palavras e/ou temas de alguma forma presentes no conto "A menor mulher do mundo".

3. Clarice LISPECTOR, "A menor mulher do mundo", Laços de familia, Rio de Janeiro, Rocco, 1983, p. 79. A partir de agora, as citações deste conto serão identificadas apenas com o número da página no próprio texto.

4. Clarice LISPECTOR, "Corças negras", A descoberta do mundo, op. cit., p. 270. Esse texto, sob o título "África", foi publicado originalmente em Fundo de gaveta, incluído na primeira edição de A legião estrangeira, de 1964. Já "Corças negras" apareceu no Jornal do Brasil, em 5 de Abril de 1969, tendo sido recolhido postumamente na coletânea de crônicas Para não esquecer, de 1979, de novo como "África", para em seguida retomar o título de 1969 por ocasião de sua inclusão no volume A descoberta do mundo, cuja primeira edição data de 1984.

5. Clarice LISPECTOR, [A Lúcio Cardoso], Correspondências, Rio de Janeiro, Rocco, 2002, p. 54.

6. Clarice LISPECTOR, "Estive em Bolama, África”, A descoberta do mundo, op. cit., p. 552.

7. Raúl ANTElo, “Mas onde fica a viagem?”, Confluenze - Rivista di Studi Iberi Americani, vol. 4, n¹. Bolonha, Dipartimento di Lingue e Letterature Straniere Moderne, Università di Bologna, 2012, p. 2.

8. Fernanda ARÊAS PEIXOTO, “A viagem como vocação - Antropologia e literatura na obra de Michel Leiris”, Michel LEIRIS, A África fantasma, trad. André Pinto Pacheco, São Paulo, CosacNaify, 2007, p. 31.

9. Raúl ANTElo, "Mas onde fica a viagem?" op. cit., p. 9.

10. Micrômegas é o personagem do conto homônimo de Voltaire (1752). Com oito léguas de altura (32 km) e uma existência que durará dezenas de milênios, ele não passa de um anão (micro) em mundos ainda maiores, embora seja um gigante(mega) em comparação aos terrestres. Voando no universo com ajuda das forças gravitacionais, pousa sobre um pequeno monte de lama, a Terra. Conversa com os "átomos humanos", cujos saberes científicos admira, mas ao conhecer sua metafísica se abandona a um riso louco que interrompe o contato. Ao partir, deixa aos "infinitamente pequenos" um livro de ensinamentos que se descobre ter as páginas em branco. 
11. Clarice LISPECTOR, "Como uma corça", A descoberta do mundo, op. cit., p. 85. A frase descreve Eremita, personagem também associada à profundeza, que Yudith Rosenbaum aproxima de Pequena Flor em "Vozes estrangeiras em Clarice Lispector - Leitura de 'Como uma corça", Cleusa RIOS P. PASSOS e Yudith ROSENBAUM (orgs.), Interpretações. Crítica Literária e Psicanálise, Cotia, São Paulo, Ateliê Editorial, 2014, p. 236 (nota de rodapé).

12. Yudith RosenbaUM, "Uma estranha descoberta. Leitura do conto 'A menor mulher do mundo', de Clarice Lispector", Revista Literatura e Sociedade, vol. 20, São Paulo, FFLCH-USP, 2015, p. 153.

13. Para além dos argumentos aqui desenvolvidos a partir da imagem da "caixa dentro de uma caixa, dentro de uma caixa", seu alcance ganha proporções notáveis dentro do conto, como sintetiza Wilton de Souza Ormundo com propriedade em sua dissertação de mestrado: “Ainda que não seja o propósito do pesquisador, ele, por meio da descoberta da pequena africana, dará acesso a outras 'caixas' que serão abertas ao longo da narrativa, surpreendendo personagens urbanos em busca do pitoresco e do bizarro e até mesmo os leitores desatentos do conto. Da mesma forma, Pequena Flor, grávida, 'mulherzinha de intolerável doçura', também constituirá uma caixa que contém em si outra caixa ainda menor: a diminuta vida de um feto em gestação. A própria estrutura narrativa criada pela autora também nos remete à imagem das caixas: o encontro do pesquisador francês com a africana poderia ser visto como uma grande caixa dentro da qual estariam depositadas outras caixas menores que seriam os relatos ou fragmentos de relatos - por vezes secretos - das histórias das personagens urbanas que observam a fotografia da mulher no jornal". Ver Figurações do grotesco nas narrativas curtas de Clarice Lispector: o fenômeno como disparador do Unheimlich, das inversões e do (des)equilibrio, Biblioteca Digital de Teses e Dissertações da USP, 2008, p. 41 [acesso em 02/11/2020] <URL : https://www.teses.usp.br/teses/ disponiveis/8/8149/tde-12082009-163845/pt-br.php>.

14. José Américo Motta Pessanha, “Clarice Lispector: $O$ itinerário da paixão”, Clarice Lispector, $A$ paixão segundo G.H., edição crítica coordenada por Benedito Nunes, Madrid-Paris-México-Buenos Aires-São Paulo-Rio de Janeiro, ALLCA XX, Coleção “Archivos”, 1996, p. 321.

15. Clarice LISPECTOR, "O que é angustia", A descoberta do mundo, op. cit., p. 693.

16. Documents, $\mathrm{n}^{\circ} 4$, Paris, Jean Michel Place, 1991, edição fac-simile, p. 215. O artigo remete ao Journal des Débats de 13 de Agosto de 1929 como fonte.

17. Yudith RoSENBAUM, “Uma estranha descoberta. Leitura do conto 'A menor mulher do mundo', de Clarice Lispector", op. cit., p. 152.

18. Berta WALDMAN, "Duas mulherzinhas", Entre passos e rastros. Presença judaica na literatura brasileira, São Paulo, Perspectiva, 2001, p. 64-65.

19. Para uma discussão sobre os diversos significados que a palavra coisa assume na obra clariciana, remeto ao excelente dossiê "As mil coisas de Clarice", organizado por Alexandre NODARI e João Camillo PENNA para a Revista Letras, n 98 (Jul./Dez. 2018), publicação semestral do Curso de Letras da UFPR, <URL : https://revistas.ufpr.br/letras>.

20. Clarice LISPECTOR, "A explicação que não explica”, op. cit., p. 365-366 (grifos nossos).

21. Para um aprofundamento do tema, remeto, entre outros, ao capítulo "Dos animais" do livro de Carlos MENDES DE SOUZA, Clarice Lispector - Figuras da escrita, São Paulo, Instituto Moreira Salles, 2012, p. 280-327, e ao artigo de Evandro NASCIMENTO "Rastros do animal humano - a ficção de Clarice", Maria Esther MACIEL (org.), Pensar/Escrever o animal. Ensaios de zoopoética e biopolítica, Florianópolis, Editora UFSC, 2011, p. 117-149.

22. Berta WALDMAN, "Duas mulherzinhas", op. cit., p. 65 (grifo da autora).

23. Wilton DE SOUZA ORMUNDO, Figurações do grotesco nas narrativas curtas de Clarice Lispector, op. cit., p. 51.

24. Embora a escritora inicie a atividade de tradução na década de 1940, tudo indica que ela só passa a traduzir de forma mais concentrada a partir dos anos 1960, embora seja difícil precisar o número de títulos, já que alguns deles não contêm data. A demissão do Jornal do Brasil, para o 
qual trabalhou entre os anos de 1967 e 1973, talvez tenha sido o desencadeador da última leva de traduções, entre as quais se encontra sua adaptação para o público juvenil de As Viagens de Gulliver, publicada pela Editora Abril Cultural em 1973, com ilustrações de Lilá Figueiredo.

25. Daniela Mercedes KAHN, "A menor mulher do mundo, de Clarice Lispector e a desmistificação do discurso da colonização”, Ângulo 111, Lorena, Unifatea, Out.-Dez, 2009, p. 28.

26. Ibid., p. 30.

27. Ao comentar o trecho, Rosenbaum observa que Clarice "desdicionariza" a palavra "amor", "amplificando seus paradoxos e eliminando hierarquias de uma construção imaginária que idealiza o amor romântico. Aqui, o amor da pigmeia se estende sem fronteiras, abarcando tudo o que vem do outro". Yudith RoSENBAUM, "Uma estranha descoberta. Leitura do conto "A menor mulher do mundo', de Clarice Lispector”, op. cit., p. 154.

28. Daniela Mercedes KAHN, "A menor mulher do mundo, de Clarice Lispector e a desmistificação do discurso da colonização", op. cit., p. 32.

29. Yudith ROSENBAUM, “Uma estranha descoberta. Leitura do conto 'A menor mulher do mundo', de Clarice Lispector", op. cit., p. 156.

30. Dizer "com espanto o nome de Deus" - a expressão aparece em "Mineirinho", Clarice LISPECTOR, A legião estrangeira, Rio de Janeiro, Editora do autor, 1964, p. 253.

\section{RESUMOS}

La rencontre d'un explorateur français avec une pygmée africaine est l'occasion pour Clarice Lispector d'interroger le voyage comme connaissance de l'altérité et de réfléchir sur l'impossibilité de déchiffrer l'autre. À l'opposé des stéréotypes de l'idéologie colonialiste, qui tend à associer la supériorité à la grandeur, l'auteur parie sur l'équivalence entre le grand et le petit, explorant un paradoxe déjà annoncé dans le titre (la plus petite femme est la plus grande de sa catégorie) qui gagne l'accent avec les procédures littéraires de réduction et d'élargissement, répétées tout au long du texte. Lispector s'aligne ainsi sur une tradition de la littérature philosophique européenne qui, de Swift à Bataille, critique la notion de mesure humaine pour affirmer le jeu complexe de proportions qui sous-tend la condition humaine. C'est pourquoi son personnage minuscule peut être rapproché de la démesure de Dieu.

The encounter of a French explorer with an African female pygmy is an occasion for Clarice Lispector to question the travel experience as knowledge of otherness and to meditate on the impossibility of deciphering the other. Unlike the commonplace of colonialist ideology, that often sustains the superiority of the largest, the author bets on the equivalence between the great and the small. Therefore, she explores a paradox that is already manifest in the title (the smallest woman is the largest in her category) and is emphasized by the literary procedures of reduction and enlargement, repeated throughout the text. Lispector's short story aligns itself with a tradition of European philosophical literature that, from Swift to Bataille, criticizes the notion of human measure in order to affirm the complex wavering of proportions that underlies the human condition. For that, the writer can approach her minimal character to the immoderation of God. 
ÍNDICE

Mots-clés: Laços de família, A menor mulher do mundo, mesure humaine, réduction, colonialisme, voyage, Bataille, Swift, Dieu

Keywords: Laços de família, A menor mulher do mundo, human measure, reduction, colonialism, travel, Bataille, Swift, God

\section{AUTOR}

\section{ELIANE ROBERT MORAES}

Universidade de São Paulo, FFLCH 